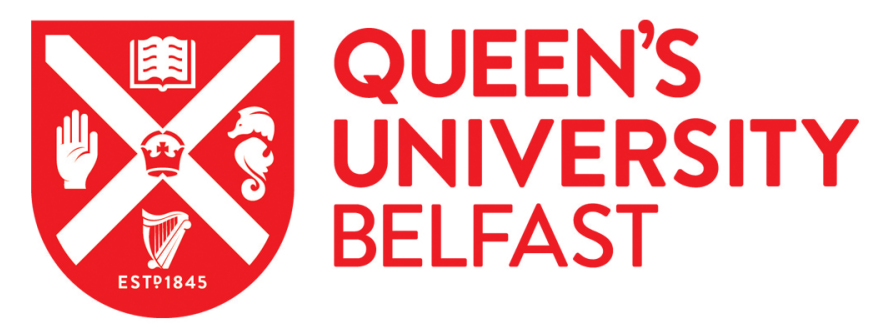

\title{
Time for Reform? Refugees, Asylum-seekers and Protection Under International Human Rights Law
}

Harvey, C. (2015). Time for Reform? Refugees, Asylum-seekers and Protection Under International Human Rights Law. Refugee Survey Quarterly, 34(1), 43-60. https://doi.org/10.1093/rsq/hdu018

\author{
Published in: \\ Refugee Survey Quarterly
}

Document Version:

Peer reviewed version

Queen's University Belfast - Research Portal:

Link to publication record in Queen's University Belfast Research Portal

\section{Publisher rights}

(c) 2014 The Author. Set statement: This is a pre-copyedited, author-produced PDF of an article accepted for publication in Refugee Survey Quarterly following peer review. The version of record, Harvey, C 2015, 'Time for Reform? Refugees, Asylum-seekers and Protection Under International Human Rights Law' Refugee Survey Quarterly, vol 34, no. 1, pp. 43-60, is available online at: http://rsq.oxfordjournals.org/content/34/1/43

\section{General rights}

Copyright for the publications made accessible via the Queen's University Belfast Research Portal is retained by the author(s) and / or other copyright owners and it is a condition of accessing these publications that users recognise and abide by the legal requirements associated with these rights.

Take down policy

The Research Portal is Queen's institutional repository that provides access to Queen's research output. Every effort has been made to ensure that content in the Research Portal does not infringe any person's rights, or applicable UK laws. If you discover content in the Research Portal that you believe breaches copyright or violates any law, please contact openaccess@qub.ac.uk. 


\title{
TIME FOR REFORM? REFUGEES, ASYLUM-SEEKERS, AND PROTECTION UNDER INTERNATIONAL HUMAN RIGHTS LAW
}

\author{
Colin Harvey*
}

\begin{abstract}
The aim is to explore the protection that international human rights law offers to refugees, asylum-seekers, and the forcibly displaced. The ambition of the global rights framework is to guarantee a defined range of rights to all human beings, and thus move the basis for normative entitlement from exclusive reliance on national membership to a common humanity. This comprehensive and international perspective remains formally tied to states - acting individually or collectively - in terms of creation and implementation. The norms must find an entry point into the empirical world, and there must be clarity on responsibilities for practical delivery. It should remain unsurprising that the expectations raised by the normative reach of the law are frequently dashed in the complex and difficult human world of instrumental politics, power, and conflict. The intention here is to outline the international human rights law context, and indicate the value and limitations for the protection of refugees and asylum-seekers. A question is then raised about possible reform.
\end{abstract}

\section{Keywords:}

Human rights, refugee law, asylum, international law

\section{Introduction}

International refugee law is a regime of protection connected to a legally constructed status with specified guarantees. ${ }^{1}$ There is a dedicated supervisory mechanism in place, in the form of the Office of the United Nations High Commissioner for Refugees (UNHCR). ${ }^{2}$ Refugees do not only benefit from the rights contained in the 1951 Convention, ${ }^{3}$ and like all those forcibly

\footnotetext{
* Professor of Human Rights Law, School of Law, Queen's University Belfast. Thanks to Dr María-Teresa GilBazo for the invitation to participate in the Workshop on "The Role of International Organizations and Human Rights Monitoring Bodies in Refugee Protection", and for her comments and support.

1 "International refugee law" as used here refers to the Convention relating to the Status of Refugees (Refugee Convention), 189 UNTS 150, 28 Jul. 1951 (entry into force: 22 Apr. 1954) and the Protocol relating to the Status of Refugees, 606 UNTS 267, 31 Jan. 1967 (entry into force: 4 Oct. 1967). There are currently 145 States parties to the 1951 Convention and 146 States parties to the 1967 Protocol.

${ }^{2}$ United Nations General Assembly, Statute of the Office of the United Nations High Commissioner for Refugees, UNGA res. 428(V), 14 Dec. 1950. For an assessment see K. O'Byrne, "Is there a Need for Better Supervision of the Refugee Convention?", Journal of Refugee Studies, 26(3), 2013, 330-359.

${ }^{3}$ Art. 5 of the Refugee Convention provides: "Nothing in this Convention shall be deemed to impair any rights and benefits granted by a Contracting State to refugees apart from this Convention."
} 
displaced, exist within a global framework of human rights standards and institutions. Refugee law's anchorage in a particular (and evolving) understanding of a created category co-exists with an international legal order that tends to emphasise "all human beings", "every human being", "everyone", "anyone", "all persons" or "no one". ${ }^{4}$ The "everyone" of international human rights law (underpinned by the principles of equality and non-discrimination ${ }^{5}$ ) suggests that what matters, as a starting point, is the fact of being "human". This does not mean that international law neglects the plight of particular individuals or does not recognize multiple identities ${ }^{6}$ or even that there is no acceptance of the place of citizenship and nationality. ${ }^{7}$ What it does promote is scepticism about the many and various ways that human beings can be rendered invisible by divisive forms of categorisation and the emergence through time of (ever more creative) humanly constructed boundaries. The problem may not necessarily arise so sharply for those who benefit already from defined guarantees but it does for those who find that the categories equate to ill-treatment. Within the human rights paradigm, the coded world of the international regulation of migration, with its terminology of "illegal persons", "irregular movement" and "failed asylum-seekers", will invite ongoing critique and concern.

\section{The International Human Rights Context}

\subsection{International human rights and refugee law}

The debates that surround the contested interaction between human rights law and refugee law can seem legalistic and odd to anyone who views these legal regimes as rooted in similar

\footnotetext{
${ }^{4}$ See, for example, from the "International Bill of Rights": United Nations General Assembly, Universal Declaration of Human Rights 1948, UNGA res. 217 A(III), 10 Dec. 1948, Arts. 1-6, 8-15, 17-29; International Covenant on Civil and Political Rights (ICCPR), 999 UNTS 171, 16 Dec. 1966 (entry into force: 23 March 1976), Arts. 6-19, 22, and 26, 168 States parties; International Covenant on Economic, Social and Cultural Rights (ICESCR), 993 UNTS 3, 16 Dec. 1966 (entry into force: 23 March 1976), Arts. 6-9, 11-13, 15, 162 States parties. ${ }^{5}$ See J. Pobjoy, "Treating Like Alike: The Principle of Non-Discrimination as a Tool to Mandate Equal Treatment of Refugees and Beneficiaries of Complementary Protection", Melbourne University Law Review, 34(1), 2010, 181-228.

${ }^{6}$ Of the many examples see: Convention on the Elimination of All Forms of Discrimination against Women, 1249 UNTS 13, 18 Dec. 1979 (entry into force: 3 Sept. 1981), 188 States parties; International Convention on the Elimination of All Forms of Racial Discrimination, 660 UNTS 195, 7 Mar. 1966 (entry into force: 4 Jan. 1969) (note the limitation in Art. 1(2) and (3)), 177 States parties; Convention on the Rights of the Child, 1577 UNTS 3, 20 Nov. 1989 (entry into force: 2 Sept. 1990), 194 States parties; International Convention on the Protection of the Rights of All Migrant Workers and Members of Their Families, 2220 UNTS 3, 18 Dec. 1990 (entry into force: 1 Jul. 2003) (note the limitation in Art. 3(d)), 47 States parties; and the Convention on the Rights of Persons with Disabilities, 2515 UNTS 3, 13 Dec. 2006 (entry into force: 3 May 2008), 151 States parties.

${ }^{7}$ The plight of stateless persons is an ongoing human rights concern, see Universal Declaration of Human Rights 1948, Art. 15; Convention Relating to the Status of Stateless Persons, 360 UNTS 117, 28 Sept. 1954 (entry into force: 6 Jun. 1960), 82 States parties, and Convention on the Reduction on Statelessness, 989 UNTS 175, 30 Aug. 1961 (entry into force: 13 Dec. 1975), 60 States parties. There is evidence in the "International Bill of Rights" of recognition of self-determination (ICCPR 1966, Art. 1 and ICESCR 1966 Art. 1 "All peoples"), citizenship (ICCPR, Art. 25) and note the reference to "non-nationals" (ICESCR, Art. 2(3)).
} 
humanitarian imperatives. ${ }^{8}$ Yet the discussions are of profound significance precisely because they impact on the approach to be taken to current arrangements and future reform. If refugee law is tired, anachronistic and a distraction then it may mean that strategic energy is directed elsewhere (the further development of international human rights law to protect all those forcibly displaced and address root causes). However, if it is regarded as of fundamental and ongoing relevance then tactical thought might be invested in its reconstruction and promotion (reform that integrates human rights advances more fully into existing international refugee law).

However it may be classified in international law, for those who seek to defend the continuing integrity and primacy of refugee law there remains a worry that the potential strength and specificity of refugee protection might be undermined in well-intentioned efforts to promote human rights. ${ }^{9}$ In this understanding, human rights law is vital but has instrumental value in keeping the refugee definition relevant and objectively delimited, ${ }^{10}$ developing the interpretation of specific guarantees of refugee law, and securing additional protections to refugees in general, and to specific groups of refugees. ${ }^{11}$

As Vincent Chetail notes, if the starting point is the primacy of refugee law then human rights law will be essentially supplementary, with the temptation among refugee lawyers to stress its limitations and supporting role. ${ }^{12}$ Chetail challenges this thinking, and argues that the "fetishism of the Geneva Convention is no longer tenable". ${ }^{13}$ He reverses the normative order

\footnotetext{
${ }^{8}$ The relationship between international humanitarian law, refugee law, and human rights law is also the source of discussion, particularly given the role of armed conflict in forced displacement, see V. Chetail, "Armed Conflict and Forced Migration: A Systematic Approach to International Humanitarian Law, Refugee law and Human Rights Law", in A. Clapham \& P. Gaeta (eds.), The Oxford Handbook of International Law in Armed Conflict, Oxford, Oxford University Press, 2014, 700-734.

${ }^{9}$ See J. C. Hathaway, "Leveraging Asylum", Texas International Law Journal, 45, 2010, 503-536, at 504: "The problem is that none of these new sources of international protection expressly defines how members of the broader class of non-returnable persons are to be treated. In contrast to the Refugee Convention [...], the new protections against refoulement are bare-bones entitlements (footnotes omitted)." Hathaway is equally concerned about "the persistent overstatement of the reach of international refugee law" (535). See also, J. C. Hathaway and J. Pobjoy, "Queer Cases Make Bad Law", New York University Journal of International Law and Policy, 44(2), 2012, 315389.

${ }^{10}$ See J. C. Hathaway and M. Foster, The Law of Refugee Status, $2^{\text {nd }}$ ed, Cambridge, Cambridge University Press, 2014; M. Foster, International Refugee Law and Socio-Economic Rights: Refuge from Deprivation, Cambridge, Cambridge University Press, 2007.

${ }^{11}$ While acknowledging the significance of the evolution of international human rights law, Hathaway emphasises the limitations, and as a consequence views the Refugee Convention as fundamental still, see J. C. Hathaway, The Rights of Refugees under International Law, Cambridge, Cambridge University Press, 2005, 119-147.

${ }^{12}$ See V. Chetail, "Are Refugee Rights Human Rights? An Unorthodox Questioning of the Relations between Refugee Law and Human Rights Law", in R. Rubio-Marín (ed.), Human Rights and Immigration, Oxford, Oxford University Press, 2014, 19-72.

${ }^{13}$ Ibid. 72 .
} 
by stressing that refugee law ${ }^{14}$ is a limited legal regime ${ }^{15}$ and supports international human rights law as the main basis now for refugee protection. He suggests that "[t]he gravitational force of human rights law has attracted the Geneva Convention into its orbit and anchored it as a satellite within the constellation of other applicable human rights treaties." 16 Chetail also draws out the political and legal implications, for example, the need to face openly the human rights violations that give rise to displacement, thus retaining a holistic perspective on refugee protection in its human rights context. ${ }^{17}$ One of the implications is that the general guarantees of human rights law may offer more protection than the specialist regime. ${ }^{18}$

Human rights law and refugee law are limited mechanisms for the protection of refugees, asylum-seekers and the forcibly displaced. Refugees benefit from both regimes, and it is evident that where applicable human rights guarantees go further than refugee law they can and should be used. The growth of complementary forms of protection - as a way of reflecting international human rights obligations - is notable. ${ }^{19}$ There is an understandable tendency among advocates of refugee law to highlight its strengths, and thus a need to be reminded of its limits and how far human rights law has travelled. Refugee law speaks to a world where international norms are realised through a carefully constructed status that many states are content to endorse and use. Human rights law is working towards a paradigm where guarantees apply to everyone, and people are then shielded from violations of accepted international norms. Whatever view is taken, it is now well-established that international human rights law is key in the encouragement of complementary forms of protection, ${ }^{20}$ and in recognising a more expansive range of reasons for flight. ${ }^{21}$ The longer term question for advocates of refugee law is whether interpretative internal renewal is sufficient or defensible. If not, then it is time for a determined reform project that would seek over time to achieve international legal change (through a new protocol to the Refugee Convention or in other ways).

\footnotetext{
14 "[T] $]$ he Geneva Convention is not a human rights treaty in the orthodox sense, for both historical and legal reasons." Ibid. 22.

15 "[C]ompared to human rights law, the Geneva Convention has much more to receive than to give." Ibid. 70.

${ }^{16}$ Ibid. 70.

${ }^{17}$ Ibid. 72. Cf. M. E. Price, Rethinking Asylum: History, Purpose, and Limit, Cambridge, Cambridge University Press, 2009, who builds a case for an expressly political understanding of asylum as against palliative or humanitarian conceptions.

${ }^{18}$ See above footnote 8, at 703: "Contrary to the common belief of many humanitarian and refugee law specialists, the most specific norm is not always the most protective one. In fact, rather the contrary is true."

${ }^{19}$ J. McAdam, Climate Change, Forced Migration and International Law, Oxford, Oxford University Press, 2012, 53.

${ }^{20}$ J. McAdam, Complementary Protection in International Refugee Law, Oxford, Oxford University Press, 2007.

${ }^{21}$ See McAdam, Climate Change, ch 3.
} 


\subsection{International human rights law: relevant standards}

International human rights law provides a wide-ranging source of norms, and is underpinned by an institutional architecture. As Sarah Joseph and Joanna Kyriakakis argue:

While international human rights law has developed to the point where States can no longer legitimately claim that human rights are a domestic matter, there are significant limits to the international community's ability to respond to recalcitrant States that persist in human rights abuses. Enforcement machinery has not kept pace with standardsetting. ${ }^{22}$

There are evident gaps, weaknesses and limits but it retains normative value. Given the reach of international human rights law, and its relevance for all those displaced and in need of protection, it could be said that the whole body of law is potentially applicable and relevant. ${ }^{23}$ The effective implementation and enforcement of international standards is also a core element of prevention, and ultimately in tackling the root causes of refugee movements. Would displacement be the global concern it is if human rights standards were adequately reflected in lived experience? The legal and political rationale of the entire system is precisely to eliminate the causes of forced displacement, as well as ensuring all persons (wherever located) are treated with dignity and respect.

The application of international human rights law may involve formal constraints, for example, the state may not be a party (this may be true also for the Refugee Convention) or reservations may be in place. The individual may not be accorded a right to petition the treatymonitoring body, and international norms may have little or no direct applicability at the national level. ${ }^{24}$ A State party that may be bound by relevant international standards may demonstrate scant practical respect and adopt a relaxed attitude towards the relevant monitoring mechanisms. In addition, although the relevance of customary international norms should not be neglected, it is not also easy to achieve agreement on their scope (or existence) in this area. ${ }^{25}$

\footnotetext{
${ }^{22}$ S. Joseph and J. Kyriakakis, "The United Nations and Human Rights" in S. Joseph and A. McBeth (eds.), Research Handbook on International Human Rights Law, Cheltenham, UK/Northampton, MA, USA, Edward Elgar, 2010, 2, and as they also note, at 26, the decisions made by the UN human rights institutions examined are not legally binding, thus enforcement is through "naming and shaming".

${ }^{23}$ Refugees are specifically mentioned in other instruments, for example, Art. 22, Convention on the Rights of the Child 1989 (see above footnote 6) which deals with "a child who is seeking refugee status or who is considered a refugee in accordance with applicable international or domestic law and procedures", Art. 22(1). See above footnote 6 for reference to some express limitations.

${ }^{24}$ For an assessment of the strengths and weaknesses of international and regional human rights supervisory mechanisms (in the context of a wider discussion on refugee protection) see, J. Whiteman and C. Nielsen, "Lessons from Supervisory Mechanisms in International and Regional Law", Journal of Refugee Studies, 26(3), 2013, 360392.

${ }^{25}$ See Hathaway, "Leveraging Asylum".
} 
The formal picture will not capture everything, as practical deployment of human rights can lead to levels of relevance and impact that are not explicable by the "pedigree" of the norm. At national level, it is sometimes possible to use international standards and guidance in useful ways that transcend reliance on notions of monism/dualism or obligations under international treaties. This is not to undermine the ultimate utility of being able to speak of binding and authoritative obligations, and legal responsibility. It is to make the simple point that in this interconnected age individuals and communities will use all the available tools to advance their arguments. On occasions this approach works.

As noted, the "International Bill of Rights" is generally insistent on inclusive applicability and the erosion of distinctions based on citizenship (for the purpose of rights protection). The Universal Declaration of Human Rights notes in its preamble that the membership that matters is of the "human family" and that "recognition of the inherent dignity and of the equal and inalienable rights of all members [...] is the foundation of freedom, justice and peace in the world". The inclusion of "the right to seek and to enjoy in other countries asylum from persecution" 26 is much commented on, as is the limitation "in the case of prosecutions genuinely arising from non-political crimes or from acts contrary to the purposes and principles of the United Nations". ${ }^{27}$ Article 14 thus envisages a right that should be enjoyed by everyone based on the protection of all persons from persecution. In order to seek asylum in other countries a person must have freedom to move or leave. The free movement rights in Article 13 include the right of everyone to "leave any country, including his [her] own, and to return to his [her] country". ${ }^{28}$ The remaining rights in the Universal Declaration of Human Rights speak to the plight of refugees and asylum-seekers on matters such as non-discrimination (Articles 2 and 7), detention (Articles 3 and 9), torture, inhuman or degrading treatment or punishment (Article 5), recognition as a person before the law (Article 6), the protection of privacy and family life (Articles 12 and 16), the right to a nationality (Article 15), freedom of thought, conscience, religion, opinion and expression (Article 18 and 19), as well as to a range of social and economic rights, such as to social security (Article 22), to work (Article 23), an adequate standard of living (Article 25), and a right to education (Article 26). The rights are

\footnotetext{
${ }^{26}$ Art. 14(1). See also, World Conference on Human Rights, Vienna Declaration and Programme of Action, , UN Doc. A/CONF.157/23, 12 Jul. 1993, para. 23: "The World Conference on Human Rights reaffirms that everyone, without distinction of any kind, is entitled to the right to seek and to enjoy in other countries asylum from persecution, as well as the right to return to one's own country."

${ }^{27}$ Art. 14(2).

${ }^{28}$ Art. 13(2). For the development of this right see V. Chetail, "The transnational movement of persons under general international law - Mapping the customary law foundations of international migration law", in V. Chetail and C. Bauloz (eds.), Research Handbook on International Law and Migration, Cheltenham, UK/Northampton, MA, USA, Edward Elgar, 2014, 1-72, 9-27.
} 
intended to be enjoyed by everyone, and include all those seeking protection whatever their formal designation or status. While most of the rights contained in the Universal Declaration of Human Rights now have a more specific normative home beyond the Declaration, the attempt to craft an international treaty on a right to asylum failed: "The refusal of States to accept an obligation to grant asylum, in the sense of admission to residence and lasting protection against the jurisdiction of another State, is amply evidenced by the history of international conventions and other instruments." 29

Despite trends evident at the regional level, ${ }^{30}$ subsequent events repeatedly demonstrated the unwillingness of states at the international level to accept asylum as a right possessed by the individual and their insistence that this "right" was an intrinsic aspect of state sovereignty. As G. S. Goodwin-Gill and J. McAdam note "State practice is replete with examples of asylum given; the humanitarian practice exists, but the sense of obligation is missing". 31

The human rights advances that continue to be made are in the development of the prohibition on return, and as a result, the emergence of complementary forms of protection. ${ }^{32}$ The non-refoulement obligation is not confined to the provisions of the Refugee Convention or to refugee law and practice. ${ }^{33}$ Human rights law increasingly drives the evolution of the norm. ${ }^{34}$

\footnotetext{
${ }^{29}$ G. S. Goodwin-Gill and J. McAdam, The Refugee in International Law, 3rd ed., Oxford, Oxford University Press, 2007, 358, and see 361-364 for the path to the 1977 Conference on Territorial Asylum, including the Declaration on Territorial Asylum (UNGA res. 2312(XXII), 14 Dec. 1967) (592-593).

${ }^{30}$ Such as the African Charter on Human and Peoples' Rights (ACHPR), 1520 UNTS 217, 27 Jun. 1981 (entry into force: 21 Oct. 1986), Art. 12(3): "Every individual shall have the right, when persecuted, to seek and obtain asylum in other countries in accordance with the law of those countries and international conventions." See also: Arab Charter on Human Rights 2004, Art. 28; American Convention on Human Rights (ACHR), 1144 UNTS 123, 22 Nov. 1969 (entry into force: 18 July 1978), Art. 22(7); Charter of Fundamental Rights of the European Union, [2000] OJ C 364/1, 18 Dec. 2000 (entry into force: 1 Dec. 2009), Art. 18.

${ }^{31}$ See above footnote 29 , at 369 .

32 See above footnote 20 .

${ }^{33}$ Art. 33(1) of the Refugee Convention is also followed by Art. 33(2). At the regional level see: OAU Convention Governing the Specific Aspects of Refugee Problems in Africa, 1001 UNTS 45, 10 Sept. 1969 (entry into force: 20 June 1974), Art. II; Cartagena Declaration on Refugees, adopted by the Colloquium on the International Protection on Refugees in Central America, Mexico and Panama, held in Cartagena on 19 - 22 November 1984, available at https://www.oas.org/dil/1984_Cartagena_Declaration_on_Refugees.pdf (last visited 2 Oct. 2014), Section III; Bangkok Principles on the Status and Treatment of Refugees 1966. See also: UN Declaration on Territorial Asylum 1967, Art. 3. R. M.M. Wallace, "The principle of non-refoulement in international refugee law", in V. Chetail and C. Bauloz (eds.), Research Handbook, 417-438; E. Lauterpacht and D. Bethlehem, "The Scope and Content of the Principle of Non-Refoulement" in E. Feller, V. Türk and F. Nicholson (eds.), Refugee Protection in International Law: UNHCR's Global Consultations on International Protection, Cambridge, Cambridge University Press, 2003, 87-163.

${ }^{34}$ As Goodwin-Gill notes: "The principle of non-refoulement ... has slipped the bounds of the 1951 Convention, requiring states at large not to return people to face the risk of persecution, torture, or other serious violations of fundamental rights." G. S. Goodwin-Gill, "Editorial: The Dynamic of International Refugee Law", International Journal of Refugee Law, 25(4), 2013, 651-666, 654. See also, Chetail, “Are Refugee Rights Human Rights?”. There is ongoing debate on the impact and implications: See Hathaway, "Leveraging Asylum", and McAdam, Complementary Protection.
} 
The United Nations Human Rights Committee (HCR) (like other treaty-monitoring bodies) embraces the protection $^{35}$ (principally on return to Article 6 and Article 7 ill-treatment), and regional courts have also willingly adopted the approach. ${ }^{36}$ The prohibition on return gained express recognition in the Convention against Torture 1984:

1. No State Party shall expel, return ("refouler") or extradite a person to another State where there are substantial grounds for believing that he would be in danger of being subjected to torture.2. For the purpose of determining whether there are such grounds, the competent authorities shall take into account all relevant considerations including, where applicable, the existence in the State concerned of a consistent pattern of gross, flagrant or mass violations of human rights.

The United Nations Committee against Torture (CAT) continues to develop its jurisprudence on the precise meaning of this obligation. ${ }^{37}$ The principle is also included in the International Convention for the Protection of All Persons from Enforced Disappearance 2006:

1. No State Party shall expel, return ("refouler"), surrender or extradite a person to another State where there are substantial grounds for believing that he or she would be in danger of being subjected to enforced disappearance.

2. For the purpose of determining whether there are such grounds, the competent authorities shall take into account all relevant considerations, including, where applicable, the existence in the State concerned of a consistent pattern of gross, flagrant or mass violations of human rights or of serious violations of international humanitarian law. $^{38}$

\footnotetext{
${ }^{35}$ This does not mean that the non-refoulement obligation is the only principle of relevance to refugees.

${ }^{36}$ Notably the European Court of Human Rights, see D.J. Harris et al, Law of the European Convention on Human Rights, 3rd ed., Oxford, Oxford University Press, 2014, 244-256. In so doing, the Court has clarified the application of Art. 3 in a range of contexts, including push-back policies (Hirsi Jamaa and others v. Italy, (2012), Appl. No. 27765/09) which has then informed the work of UNHCR, among others, see UNHCR, Global Initiative on Protection at Sea, Geneva, UNHCR, 2014. See further A. Klug, "Strengthening the Protection of Migrants and Refugees in Distress at Sea through International Cooperation and Burden-Sharing", International Journal of Refugee Law, 26(1), 2014, 48-64.

${ }^{37}$ United Nations Committee against Torture, General Comment 1: Implementation of Article 3 of the Convention in the Context of Article 22, UN Doc. A/53/44, 21 Nov. 1997, annex IX; United Nations Committee against Torture (CteAT), N.T.W v Switzerland, (2012) Communication No. 414/2010; CteAT, Jahani v Switzerland, (2011), Communication No. 357/08 (2011).

${ }^{38} 2715$ UNTS Doc.A/61/448, 20 Dec. 2006 (entry into force: 23 Dec. 2010), Art. 16.
} 
As noted, other elements of the international human rights system recognize the prohibition, ${ }^{39}$ and it is also adopted at the regional level. ${ }^{40}$ Other rights protected in international law will apply to refugees, for example, the use of detention around the world has attracted concern. One the of limitations remains, however, that the international mechanisms are not always clear about what then positively happens to those who cannot be returned for human rights reasons. ${ }^{41}$ This is addressed to some extent by the creation of complementary protection systems, and it is possible to draw together (from the body of existing international human rights law) the basic obligations that should apply. Nevertheless, despite its flaws it is refugee law's ability to address this question with more precision that remains its most valuable characteristic. It is equally the case that international human rights law is not silent on this matter.

\section{Using International Human Rights Protection}

The aim now is to consider contexts where the normative framework is used. One way of doing this is to reflect on the work of the HRC in relevant individual communications. ${ }^{42}$ As indicated, the ICCPR 1966 reflects the language of "humanity" with its references to "all individuals", "every human being", "everyone" and "all persons", and the HRC has confirmed this inclusive approach. ${ }^{43}$ How has the Committee dealt with communications in this area?

\subsection{United Nations Human Rights Committee}

Arguably, it is the work on non-refoulement that has thus far proved the most instructive. The Committee contributes to the evolution of the principle through its interpretation of relevant provisions of the ICCPR:

Moreover, the article 2 obligation requiring that States Parties respect and ensure the Covenant rights for all persons in their territory and all persons under their control entails an obligation not to extradite, deport, expel or otherwise remove a person from

\footnotetext{
${ }^{39}$ See, for example, United Nations Committee on the Rights of the Child, General Comment 6: Treatment of Unaccompanied and Separated Children Outside their Country of Origin, UN Doc. CRC/GC/2005/6, 1 Sept. 2005; United Nations Committee on the Elimination of Racial Discrimination, General Recommendation 22: Article 5 and Refugees and Displaced Persons, UN Doc. A/51/18, 23 Aug. 1996.

${ }^{40}$ See above footnote 36, and American Convention on Human Rights, Art. 22(8); Inter-American Convention to Prevent and Punish Torture, 67 OASTS, 9 Dec. 1985 (9 Dec. 1985), Art. 13(4); Charter of Fundamental Rights of the European Union, Art. 19(2).

${ }^{41}$ On this point, with reference to the European Court of Human Rights, see H. Lambert, "Introduction: European refugee law and transnational emulation", in H. Lambert, J. McAdam, and M. Fullerton (eds.), The Global Reach of European Refugee Law, Cambridge, Cambridge University Press, 2013, 23.

${ }^{42}$ The work of the United Nations Committee against Torture is addressed elsewhere in this Special Issue. See F. M. Mariño Menéndez, "Recent Jurisprudence by the United Nations Committee Against Torture and the International Protection of Refugees".

${ }^{43}$ See, United Nations Human Rights Committee, General Comment No. 31: The Nature of the General Legal Obligation Imposed on States Parties to the Covenant, UN Doc. CCPR/C/21/Rev.1/Add. 13, 26 May 2004. For analysis see A. Duffy, "Expulsion to Torture? Non-refoulement in International Law", International Journal of Refugee Law, 20(3), 2008, 373-390, at 384-385; S. Persaud, "Protecting refugees and asylum seekers under the International Covenant on Civil and Political Rights", New Issues in Refugee Research, 132, 2006.
} 
their territory, where there are substantial grounds for believing that there is a real risk of irreparable harm such as that contemplated in articles 6 and 7 either in the country to which removal is to be effected or in any country to which the person may subsequently be removed. ${ }^{44}$

In applying Articles 6 and 7 the Committee stresses the personal nature of the risk, and that there is a "high threshold" to be attained before substantial grounds will be established of a real risk of irreparable harm. ${ }^{45}$

The ICCPR 1966 is not only relevant to return but also applies to, for example, detention. ${ }^{46}$ Where there is a finding of a violation, the Committee notes that the individual has a right to "an effective and enforceable remedy". ${ }^{47}$ The Committee is also, through its Concluding Observations, able to offer specific recommendations on how refugee and asylum processes might be improved. ${ }^{48}$

Given the use of the ICCPR in extradition, deportation or expulsion it is worth exploring how the Committee has approached this task in selected communications. $X v$ Denmark involved an Eritrean national ordered to leave Denmark following an unsuccessful asylum application. ${ }^{49} \mathrm{He}$ argued that his removal to Eritrea would violate Articles 7 and 18 (the author's Article 14 claim - relating to the Refugee Appeals Board - was held to be inadmissible ${ }^{50}$ ) as he would refuse to perform military service due to his religious beliefs, and thus face ill-treatment. The author also indicated his inability to demonstrate he had left Eritrea lawfully and the fact of his asylum application, would further contribute to his treatment on return. In concluding that there would be a violation of Article 7 if the author was removed, the Committee was influenced by the "credible sources [that] indicate that illegal entrants, failed asylum seekers

\footnotetext{
${ }^{44}$ United Nations Human Rights Committee, General Comment No. 31, para. 12. See also: United Nations Human Rights Committee, General Comment No. 20: Article 7 (Prohibition of torture, or other cruel, inhuman or degrading treatment or punishment) (Replaces general comment No. 7), UN Doc. HRI/GEN/1/Rev.9 (Vol. I), 10 March 1992.

${ }^{45}$ United Nations Human Rights Committee (HRC), X v Denmark (2014), Communication No. 2007/2010, para. 9.2 .

${ }^{46}$ HRC, F.K.A.G. v Australia (2013), Communication No. 2094/2011.

${ }^{47} X v$ Denmark, see above footnote 45, para. 9.7. See HRC, M.I. v Sweden (2013), Communication No. 2149/2012, para. 9, in deportation cases an effective remedy includes: "full reconsideration of her claim regarding the risk of treatment contrary to article $7[\ldots]$ taking into account the State party's obligations under the Covenant and the Committee's present Views. In the meantime, the State party is requested to refrain from expelling the author to Bangladesh while her request for asylum is under reconsideration. The State party is also under the obligation to take steps to prevent similar violations in the future."

${ }^{48}$ See, for example, United Nations Human Rights Committee, Concluding Observations on the fourth periodic report of Ireland, UN Doc. CCPR/C/IRL/CO/4, Jul. 2014, para. 19.

${ }^{49} \mathrm{X} v$ Denmark, see above footnote 45 .

${ }^{50}$ Ibid. para. 8.5.
} 
and draft evaders risk serious ill-treatment upon repatriation to Eritrea". ${ }^{51}$ The Committee concluded:

[T] hat the State party did not adequately address the concern that the author's personal circumstances ... might lead to him being designated as a failed asylum seeker and as an individual who has not completed the compulsory military service requirement in Eritrea or as a conscientious objector. ${ }^{52}$

M.I. $v$ Sweden involved the question of sexual orientation, forced marriage, and deportation to Bangladesh. ${ }^{53}$ The author was living in Sweden, and was forced to return to Bangladesh (when her husband learned of her sexual orientation), where she alleged she was detained, beaten and raped (and that her partner was kidnapped). She subsequently returned to Sweden where she claimed asylum (on the basis of the treatment of lesbians in Bangladesh by state and non-state actors). Her asylum claim in Sweden was rejected, and the issue for the Committee was whether there would be a violation of Article 7 if she was deported. The Committee noted that the author's allegation that she was raped by the Bangladeshi police while in detention was not challenged, her sexual orientation was not contested (and it was in the public domain), her mental health was affected, ${ }^{54}$ and stressed that the inconsistencies and any ambiguity in her evidence did not undermine the reality of the risk. ${ }^{55}$ The Committee also observed that the existence of a law criminalising homosexual acts in Bangladesh stigmatised the LGBT community and "constitutes an obstacle to the investigation and sanction of persecution against these persons". 56 The Committee indicated:

Against the background of the situation faced by persons belonging to sexual minorities, as reflected in reports provided by the parties, the Committee is of the view that, in the particular case of the author, the State party failed to take into due consideration the author's allegations regarding the events she experienced in Bangladesh because of her sexual orientation - in particular her mistreatment by the police - in assessing the alleged risk she would face if returned to her country of origin. ${ }^{57}$

In S.Y.L. v Australia the questions included return where it was claimed there would be no access to appropriate medical care. ${ }^{58}$ The author and his family faced deportation to Timor-

\footnotetext{
51 Ibid. para. 9.3. The source cited by the Committee is the UNHCR, Eligibility Guidelines for Assessing the International Protection Needs of Asylum Seekers from Eritrea, Un Doc. HCR/EG/ERT/11/01, 20 Apr. 2009.

${ }^{52}$ See above footnote 45, para. 9.3.

${ }^{53}$ HRC, M.I. v Sweden (2013), Communication No. 2149/2012.

${ }^{54}$ Ibid., para. 7.2.

${ }^{55}$ Ibid., para. 7.5 .

${ }^{56}$ Ibid., para. 7.5.

${ }^{57}$ Ibid., para. 7.5.

${ }^{58}$ HRC, S.Y.L. v Australia (2013), Communication No. 1897/2009.
} 
Leste (following unsuccessful claims for refugee and humanitarian protection in Australia) and argued that this would "deny them their right to health, which they could not receive anywhere else". ${ }^{59}$ While there was acknowledgement that the author and his wife did "suffer from several chronic illnesses", ${ }^{60}$ the Committee raised concerns about the level of detail in the medical reports provided by the author, noted that reasons had not been provided why he could not live elsewhere in the country (where medical treatment was available), and there was no “information indicating an acute condition that would make the author's return to Timor Leste an immediate threat to his health". ${ }^{61}$ The Committee concluded that the claim was inadmissible.

The questions raised by the Australian approach to detention were addressed in F.K.A.G. et al. $v$ Australia. ${ }^{62}$ The 37 authors ${ }^{63}$ of this communication were held in Australian immigration facilities, and alleged violations of a range of provisions of the ICCPR $1966 .{ }^{64}$ While there was acceptance of their protection needs (the authors were recognized as refugees either by the Australian authorities or $\mathrm{UNHCR}^{65}$ ) the adults were refused visas due to adverse security assessments and thus detained pending removal. ${ }^{66}$ The authors challenged their treatment, and alleged breaches of Articles 9(1), (2), (4); 7; 10(1); 17(1); 23(1); 24(1), raising questions concerning the automatic nature of detention, the security assessments, the remedies available, the personal impact of detention, and the implications for family life. The State party contested these allegations, and highlighted, for example, the availability of judicial review, and acknowledged that they were refugees and that the non-refoulement obligation applied to any removal. ${ }^{67}$ The Committee concluded that Australia had violated Article 9(1), as there was no individual basis for the detention, no consideration of other less invasive measures and the authors were deprived of legal safeguards (there was also a separate violation of Article 9(4)). ${ }^{68}$ The Committee accepted that asylum-seekers who enter unlawfully may be detained "for a brief initial period" but that any additional detention is arbitrary "absent particular reasons specific

\footnotetext{
${ }^{59}$ Ibid., para 3.2 .

${ }^{60} \mathrm{Ibid}$., para 8.4 .

${ }^{61}$ Ibid., para 8.4 .

${ }^{62}$ HRC, F.K.A.G. et al. v Australia (2013), Communication No. 2094/201.

63 "They are all Sri Lankan citizens of Tamil ethnicity except one author who is a Myanmarese citizen of Rohingya ethnicity" para. 1.1, and para. 2.1; one of the authors "is a minor child born in detention in Australia" (there were three children involved in this case and they "were granted protection visas"), Ibid., para. 2.4.

${ }^{64}$ Arts. $7 ; 9$ paras. 1,2 and $4 ; 10$ para. $1 ; 17$ para. $1 ; 23$ para. $1 ; 24$ para. 1.

${ }^{65}$ See above footnote 62, para. 2.3.

${ }^{66}$ See above footnote 62, para. 2.6.

${ }^{67}$ See above footnote 62, para. 4.2.

68 See the Individual Opinion of Sir Nigel Rodley and the view that the finding on Art. 9(4) was "circular and superfluous". Also note that the Committee held the "family life" complaints under Arts. 17(1), 23(1) and 24(1) to be inadmissible, para. 8.7. For an example of an earlier case involving immigration detention in Australia see: HRC, Bakhtiyari v Australia (2003), Communication No. 1069/2002.
} 
to the individual". ${ }^{69}$ There should be a case-by-case assessment and "less invasive measures" must be taken into account. ${ }^{70}$ The decision must "take into account the needs of children and the mental health conditions of those detained". ${ }^{71}$ The Committee also noted that "[i]ndividuals must not be detained indefinitely on immigration control grounds if the State party is unable to carry out their expulsion." $" 72$

For most of the authors the Committee held that there was no breach of Article 9(2) but for the "Oceanic Viking Group" 73 a prior security assessment provided the basis for the initial detention (with no specific reasons or information) and as a result there was a violation. The conditions of detention, and their protracted and indefinite duration, contributed to a breach of Article 7 as this was "cumulatively inflicting serious psychological harm upon them". ${ }^{74}$ The HRC addressed similar issues in M.M.M. et al v Australia and with largely the same substantive outcome. ${ }^{75}$

Choudhary v Canada involved the deportation of a Pakistani national who feared illtreatment (including from a Sunni extremist group) as a result of a fatwa, and a criminal charge of blasphemy. ${ }^{76} \mathrm{He}$ claimed that his rights - and the rights of his wife and 3 of his children would be violated. His refugee application in Canada was rejected on credibility grounds. In finding a violation of Articles 6(1) and 7 (in the event of the deportation being carried out) the Committee indicated that religious minorities faced "fierce persecution and insecurity" and lacked effective state protection, ${ }^{77}$ the government had dropped a proposed amendment to the blasphemy code, and there was an "upsurge in blasphemy cases in 2012". ${ }^{78}$ Although there was evidence that death sentences were not carried out, "several instances of extra-judicial assassination, by private actors, of members of religious minorities accused under the blasphemy law have been reported, without the Pakistani authorities being willing or able, to protect them". 79

In Al-Gertani v Bosnia and Herzegovina an Iraqi national in an immigration detention centre, who had deserted from the army (with consequences in particular for his brother), and

\footnotetext{
${ }^{69}$ See above footnote 62, para. 9.3.

${ }^{70}$ See above footnote 62, para. 9.3.

${ }^{71}$ See above footnote 62, para. 9.3.

${ }^{72}$ See above footnote 62, para. 9.3.

73 "Five of the authors ... were brought to Australia after having been rescued at sea by Australian customs vessel Oceanic Viking which disembarked them in Indonesia", see above footnote 62, para. 2.2.

${ }^{74}$ See above footnote 62, para. 9.8 .

${ }^{75}$ HRC, M.M.M. et al v Australia (2013), Communication No. 2136/2012.

${ }^{76}$ HRC, Choudhary v Canada (2013), Communication No. 1898/2009.

${ }^{77}$ Ibid., para. 9.7.

${ }^{78}$ Ibid., para 9.7.

${ }^{79}$ Ibid., para. 9.8
} 
whose asylum claim was dismissed based on security concerns and credibility (he had gained citizenship in Bosnia and Herzegovina in 1996 under a false name), argued that his return to Iraq would breach several ICCPR rights. ${ }^{80}$ His complaints in relation to Articles 9(1), (2), (4); 17; 23 and 24 were held to be admissible, the rest were not. The Committee concluded that the State party had breached Article 9(1) as it had "failed to justify the necessity of continued and prolonged detention ... and to demonstrate that other, less intrusive measures could not have achieved the same end". ${ }^{81}$ There were also violations of Articles 9(2) and (4), due to the lack of information provided to the author, and the nature and conduct of the review by the courts in the State party. ${ }^{82}$ In finding that there would be a breach of Articles 17 and 24 (impact on family life) the Committee underlined the impact that the national security rationale had on the treatment of the author; he was not in a position to deal with the allegations that he posed a security threat.

In Hamida $v$ Canada the author (a Tunisian national living in Canada) faced expulsion to Tunisia. ${ }^{83}$ His refugee claim in Canada was rejected, one of the reasons being (credibility and alleged lack of evidence were among the other factors ${ }^{84}$ ) that the Refugee Convention did not apply by virtue of Article 1(F) (a) and (c). ${ }^{85}$ The author was a former member of the "Political Security Section" of the Ministry of Interior, and given that torture was practised by the Section on a routine basis, the authorities had concluded that he should be excluded. ${ }^{86}$ The complaint included the argument that he would face detention, and a risk of torture or disappearance on return. ${ }^{87}$ The Committee highlighted that:

[W] hen the author's claims were considered by the State party's authorities, much weight was given to the fact that the Convention relating to the Status of Refugees did not apply to him and it appears that inadequate consideration was given to the specific rights of the author under the Covenant and such other instruments as the Convention Against Torture. ${ }^{88}$

\footnotetext{
${ }^{80}$ HRC, Al-Gertani v Bosnia and Herzegovina (2013), Communication No. 1955/2010.

${ }^{81}$ Ibid., para. 10.4 .

${ }^{82} \mathrm{Ibid}$., paras. 10.5 and 10.6.

${ }^{83}$ HRC, Hamida v Canada (2010), Communication No. 1544/2007. See also HRC, Warsame v. Canada (2011), Communication No. 1959/2010, on the question of proposed deportation as a result of the author's criminal activity in Canada, the significance of retaining a focus on the reality of the risk of irreparable harm (here in relation to Art.6), as well as the other guarantees afforded by the ICCPR (note in particular the different views on Art.12).

${ }^{84}$ Hamida, ibid., para. 4.3

${ }^{85}$ Ibid., para. 2.4.

${ }^{86}$ Ibid., para. 2.4.

${ }^{87}$ Ibid., para. 8.3.

${ }^{88}$ Ibid., para. 8.5.
} 
The author's Article 6 complaint did not convince the Committee, and was found to involve "no more than general allegations mentioning the risk of detention inhuman conditions and the fact that he would be deprived of access to justice and might disappear" ${ }^{89}$ The Committee was persuaded by the Article 7 complaint, and concluded that substantial evidence was provided that the author did have a real and personal risk. ${ }^{90}$ As a consequence of his dissent he had been disciplined and detained (with pressure exerted on his family), his asylum application in Canada would, the Committee noted, also mark him out as an opponent of the regime. ${ }^{91}$

The matter of diplomatic assurances in a security context was addressed in Alzery $v$ Sweden. ${ }^{92}$ In this case the author was returned to Egypt following assurances (and subjected to ill-treatment), and argued that in so doing Sweden violated several provisions of the ICCPR. On the question of assurances the Committee stated:

In determining the risk of such treatment in the present case, the Committee must consider all relevant elements, including the general situation of human rights in the State. The existence of diplomatic assurances, their content and the existence and implementation of enforcement mechanisms are all factual elements relevant to the overall determination of whether, in fact, a real risk of proscribed ill-treatment exists. ${ }^{93}$ As a result of findings by the CAT in Agiza $v$ Sweden, ${ }^{94}$ the State party "conceded that there was a risk of ill-treatment" and that it "relied on the diplomatic assurances alone for its belief". 95 In finding that the expulsion did amount to a violation of Article 7, the Committee noted the factors that would determine whether any assurances would be sufficiently robust. ${ }^{96}$ There was "no mechanism for monitoring their enforcement" and no arrangements for "effective implementation", the visits that did take place only started after five weeks, and did not "conform to key aspects of international good practice". 97 The Committee also upheld the

\footnotetext{
${ }^{89}$ Ibid., para. 8.6.

${ }^{90}$ Ibid., para. 8.7. The Committee underlined, "his dissent in the Tunisian police, his six-month police detention, the strict administrative surveillance to which he was subjected and the wanted notice issued against him by the Ministry of the Interior".

${ }^{91}$ Ibid., para. 8.7. As in other such communications, the Committee held it unnecessary to examine the Articles 17 and 23 claims, para. 8.8.

${ }^{92}$ HRC, Alzery v Sweden (2006), Communication No. 1416/2005. For comment see, E. Guild, “Asymmetrical sovereignty and the refugee: diplomatic assurances and the failure of due process, Agiza v. Sweden and Alzery v. Sweden" in J. C. Simeon (ed.), Critical Issues in International Refugee Law: Strategies Toward Interpretative Harmony, Cambridge, Cambridge University Press, 2010, 119-142.

${ }^{93}$ Alzery, ibid., para. 11.3.

${ }^{94}$ CteAT, Agiza v Sweden (2005), Communication No. 233/2003.

${ }^{95}$ See Alzery above footnote 92, para. 11.4. On the question of assurances in the context of the death penalty see, for example, HRC, Fong v Australia (2009), Communication No. 1442/2005, HRC, Kindler v Canada (1993), Communication No. 470/1991, HRC, Judge v Canada (2003), Communication No. 829/1998.

${ }^{96}$ See Alzery above footnote 92, para. 11.5.

${ }^{97}$ See Alzery above footnote 92, para. 11.5. There was no insistence on "private access to the detainee" and an absence of "appropriate medical and forensic expertise".
} 
Article 7 claims in relation to the ill-treatment by "foreign agents" at the airport, and the associated complaints around the inadequacies of the subsequent investigation, ${ }^{98}$ as well as the allegations on the lack of an "independent review of the Cabinet's decision to expel". 99

By the nature of refoulement, effective review of a decision to expel to an arguable risk of torture must have an opportunity to take place prior to expulsion, in order to avoid irreparable harm to the individual and rendering the review otiose and devoid of meaning. The absence of any opportunity for effective, independent review of the decision to expel in the author's case accordingly amounted to a breach of article 7, read in conjunction with article 2 of the Covenant. ${ }^{100}$

The case of Ahani $v$ Canada again raised the interaction between national security and refugee protection. ${ }^{101}$ In this instance, an Iranian citizen was initially granted refugee status in Canada but then (following intelligence reports indicating he was working for the Iranian Ministry of Intelligence and Security) held to be inadmissible, and he was detained until his eventual deportation (before the Committee's determination). In finding violations of Articles 9(4), 13 (read with Article 7), and concluding that the State party had breach its obligations under the Optional Protocol, the Committee highlighted several procedural problems with challenges available against the security certification system in Canada. ${ }^{102}$ Although the Committee did not need to decide on the question of the risk of torture or ill-treatment and whether it had in fact taken place on return, it did note that "the prohibition on torture, including as expressed in article 7 of the Covenant, is an absolute one that is not subject to countervailing considerations". ${ }^{103}$ The appropriate effective remedy outlined by the Committee included "to make reparation to the author if it comes to light that torture was in fact suffered subsequent to deportation" as well as "to avoid similar violations in the future" and this to include “appropriate steps to ensure that the Committee's requests for interim measures of protection will be respected". 104

These are only some of the communications received by the Committee. Although the work of the CAT tends to attract the most attention (on non-refoulement) the HRC does have a wider role in the refugee and asylum context. These examples illustrate the relevance of the

\footnotetext{
${ }^{98}$ See Alzery above footnote 92 , para. 11.7.

${ }^{99}$ See Alzery above footnote 92, para. 11.8.

${ }^{100}$ See Alzery above footnote 92, para. 11.8. Note the Committee found no violation of Article 13 but did conclude that Article 1 of the Optional Protocol had been violated "the State party executed the expulsion in full knowledge that advice of its decision would reach counsel after the event" (para. 11.11).

${ }^{101}$ HRC, Ahani v Canada (2004), Communication No. 1051/2002.

102 Ibid., paras. 10.1-13.

${ }^{103}$ Ibid., para. 10.10.

${ }^{104}$ Ibid., para. 12.
} 
international human rights machinery in cases where refugee status is refused domestically and return proposed, in contexts where national security and deportation interact, in setting out the rights that should apply when detention is contemplated, and in placing rights-based boundaries on the inter-state use of assurances. The limitations are well-known and often emphasised, but the role of the Committee in these individual communications, and in the process of standardsetting through interpretative guidance, is significant. The international treaty-monitoring mechanisms can help to remind states that negative credibility assessments, a sharpened focus on inconsistencies, the anxieties raised by legitimate security concerns, and the domestic public policy concerns on migration, should not override the centrality of a rigorous assessment of the reality of the risk on return. The work can also give meaning to what a rights-based approach should be not simply on non-refoulement but on aspects of the life experience of the forcibly displaced.

\subsection{Other International Human Rights Mechanisms}

The HRC is not the only international mechanism of relevance to the protection of refugees and asylum-seekers. Other treaty-monitoring bodies have experience of dealing with related human rights concerns. For example, the Committee on the Elimination of Discrimination against Women has indicated that:

[A]rticle 2(d) of the Convention encompasses the obligation of States parties to protect women from being exposed to a real, personal and foreseeable risk of serious forms of gender-based violence, irrespective of whether such consequences would take place outside the territorial boundaries of the sending State party (footnote omitted). ${ }^{105}$

In Rivera $v$ Canada the question of asylum from domestic violence was raised before the Committee. ${ }^{106}$ The author here argued that her deportation to Mexico (and that of her two children) would violate Articles 1, 2(a)-(d), 5(a) and 24 of the Convention. The Canadian authorities did note that gender-based persecution claims could be successful, but that in this instance the author had not demonstrated the relevant risk. ${ }^{107}$ Canada argued successfully here that the author had failed to exhaust domestic remedies (the author should have made use of the available remedy of judicial review). ${ }^{108}$

\footnotetext{
${ }^{105}$ Committee on the Elimination of Discrimination against Women (CEDAW), $N v$ The Netherlands (2014), Communication No. 39/2012, para 6.4. The Committee concluded that this communication was inadmissible.

${ }^{106}$ CEDAW, Rivera v Canada (2011), Communication No. 26/2010.

${ }^{107} \mathrm{Ibid}$., para. 4.2.

${ }^{108}$ Ibid., para. 6.3. See also the admissibility decision in CEDAW, MPM v Canada (2012), Communication No. $25 / 2010$
} 
In its General Recommendation No. 30 "on women in conflict prevention, conflict and post-conflict situations" the Committee underlines the complementarity of international humanitarian, refugee and criminal law. ${ }^{109}$

The provisions of the Convention prohibiting discrimination against women reinforce and complement the international legal protection regime for refugees and displaced and stateless women and girls in many settings, especially because explicit gender equality provisions are absent from relevant international agreements, notably the 1951 Convention relating to the Status of Refugees and its 1967 Protocol. ${ }^{110}$

The Committee highlights why these recommendations can be of some practical value by making precise and detailed suggestions that give meaning to the relevant standards. ${ }^{111}$

In Dawas and Shava $v$ Denmark the Committee on the Elimination of Racial Discrimination held that Denmark had violated Articles 2(1)(d) and 6 of the Convention as a result of a failure to protect the petitioners (refugees living in Denmark), and a failure to conduct an effective investigation into a racist attack. ${ }^{12}$ The case is illustrative of the potential of the process for challenging racial discrimination and racist violence directed against refugees. The problems faced by those who are not recognised as refugees and also not returned for humanitarian reasons is illustrated in A.M.M. v Switzerland. ${ }^{113}$ The petitioner applied for asylum in Switzerland (fearing persecution on return to Somalia) and was not granted refugee status, but was also not returned for humanitarian reasons due to the country situation in Somalia at the time. The plight of the petitioner in Switzerland is illustrative of the problems faced by those who are not granted refugee status (he held an "F" permit that signalled his temporary admission status). The complaint was that the treatment experienced was a result of the petitioner's ethnic origin or Somali nationality and violated the Convention. The State party argued, however, that the issues raised related to his status under the law (on temporary admission) that applied in Switzerland to all foreign nationals. The Committee's view was that the petitioner had not "unequivocally established" that the discriminatory treatment was the result of his ethnic origin or nationality and therefore there was no violation of Article $1 .{ }^{114}$

\footnotetext{
${ }^{109}$ Committee on the Elimination of Discrimination against Women, General recommendation No. 30 on women in conflict prevention, conflict and post-conflict situations, UN Doc. CEDAW/C/GC/30, 18 Oct. 2013, paras. 1924 and see also paras. 53-57.

${ }^{110}$ Ibid., para. 22.

${ }^{111}$ Ibid., para. 57(a)-(i). See also General Recommendation No. 32 on the gender-related dimensions of refugee status, asylum, nationality and statelessness of women, UN Doc. CEDAW/C/GC/32, 5 Nov. 2014.

112 Committee on the Elimination of Racial Discrimination (CERD), Dawas and Shava v Denmark (2012), Communication No. 46/2009.

113 CERD, A.M.M. v Switzerland (2014), Communication No. 50/2012.

${ }^{114}$ Ibid., para. 8.6.
} 
Nevertheless, the Committee still commented on the position of those with temporary admission status in Switzerland, drew the attention of the State party to its General Recommendation No. 30 (2004), ${ }^{115}$ and recommended a review of current law and practice. ${ }^{116}$

\section{Conclusion}

The potential normative reach of international human rights law is impressive, and its growth in a relatively short historical period is remarkable. All those displaced are in principle included within its embrace; status and location are not primary concerns. This does not mean that states are prepared to welcome a new and expanded approach to the international definition of "refugee" or are now more open to accepting a guaranteed right to be granted asylum. The instrumental imperatives of migration management continue to shape national, regional and international responses. It also does not prohibit states from regulating migration or from making distinctions in national law and practice that respect the boundaries established by international human rights law.

Human rights law informs refugee law to such an extent (in definitional and substantive terms) that the relevance of the latter is questioned. ${ }^{117}$ It shifts the focus towards human rights violations and abuses, including those that cause displacement. The evolution of the principle of non-refoulement stands out as a striking contribution. It is able to evolve at such a pace at the international and regional levels, precisely because mechanisms of monitoring, supervision and enforcement exist and are tied to the relevant rights. Refugee law, with its essentially devolved system of implementation, can achieve this too through developments at the national level, comparative experience, international interventions and the work of UNHCR. There is a tension that will remain. The interpretative gains achieved through adjudicative mechanisms, and the interventions of the international human rights regime, can be contested by states. Over the longer term the question of explicit reform of international refugee law should not be neglected. Rather than invite the emergence of piecemeal and variable forms of status might there be scope for international refugee law to draw relevant international human rights trends expressly into its domain? Is it time to accept the implications of the advance of human rights and open up the concept of refugee once again so that it reflects the reality of displacement more fully, with all the associated implications for UNHCR and other institutions? Or is the better option to continue to encourage support for the Refugee Convention (properly understood), embed the current definitional framework further (informed by human rights

\footnotetext{
115 Ibid., para. 10.

${ }^{116}$ Ibid., para 11.

${ }^{117}$ Chetail, “Are Refugee Rights Human Rights?”.
} 
norms) and seek equal treatment for the other complementary or subsidiary forms of protection that emerge? 